https://doi.org/10.18485/iipe_response2covid19.2021.ch20

\title{
PUBLIC PROCUREMENTS DURING THE COVID-19 PANDEMIC TIME - LESSONS FOR THE REPUBLIC OF SERBIA
}

\author{
Jelena Kostić ${ }^{1}$ \\ Marina Matić Boškovićz
}

\begin{abstract}
The COVID-19 pandemic has highlighted variations in the governments' response to health crises and interventions across states, not only in the prevention of pandemics but also in their economies and public expenditure. As a result of the pandemic, the majority of states declared an emergency in accordance with the provisions of their constitutions to enable the introduction of restrictions needed for the prevention of virus spread. Having in mind the new circumstances that introduced limitations in all areas, the question of the implementation of initiated public procurements and the realization of new ones was raised. Some goods, such as medical materials necessary for the treatment of patients with coronavirus and the prevention of its spread, had to be obtained in an extremely short time. That was aggravated by the shortage of supplies, the impossibility of market research and the lack of planned funds in the budget. EU rules allow deviations from regular procedures in such urgent and unpredicted situations. However, a special challenge for all countries was the prevention of abuses, conflict of interest and other illegalities in public procurement during the emergency.

In the paper, the authors start from the assumption that it is necessary to increase control and transparency of public procurement in the Republic of Serbia, especially in emergency situations, bearing in mind the corruption risks and challenges raised by the European Commission's progress reports. To prove the assumption and provide guidelines for improving regulations and practices, in the first part of the paper, the authors analysed the relevant European standards on public procurement and the measures taken by the EU member states to implement public procurement procedures quickly and efficiently in times of emergency, with the aim of identifying good practices. In the second part of the paper, the authors
\end{abstract}

\footnotetext{
${ }^{1}$ Senior Research Associate, Institute of Comparative Law, Belgrade, Serbia, j.kostic@iup.rs.

${ }^{2}$ Research Associate, Institute for Criminological and Sociological Research, Belgrade, Serbia,m.m.boskovic@roldevelopmentlab.com.
} 
analyse the legislation of the Republic of Serbia and the approach taken during the pandemic against the EU member states' comparative examples and practices. In addition, the authors propose recommendations for the improvement of transparency and competitiveness in public procurement in times of emergency.

Keywords: public procurement, pandemic, COVID-19, deviations, transparency

\section{INTRODUCTION}

The pandemic caused by the COVID-19 virus was officially declared on March 11, 2020, by the World Health Organisation (Time, 2021).

Given the unpredictability and danger of the disease, a significant number of countries have adopted emergency declarations to enable the adoption of measures for the prevention of virus spread. In the Republic of Serbia, the Decision on declaring the COVID-19 disease caused by the SARS-Cov-2 virus a contagious disease was first made on March 10, 2020 (The Official Gazette of the Republic of Serbia, No. 23/2020), followed by the Decision on declaring a state of emergency on March 15, 2020 (The Official Gazette of the Republic of Serbia, No. 29/2020). At the beginning of the pandemic, there was a need for the procurement of goods that was not foreseen in the financial plans of the organizations of obligatory social and health insurance, as well as in the budget. To enable urgent public procurement, funds from the current budget reserve were allocated to other appropriations or in the form of grants from the budget transferred to mandatory social and health insurance organizations. ${ }^{3}$ The adoption of such decisions enabled the use of funds for the procurement of medical equipment and other goods and services of importance for the protection of human life and health in a short period of time. However, in addition, it was necessary to ensure compliance with the principles of public procurement, which are established by both international standards and national legislation. Emergency public procurement also represents public spending, so it was necessary to respect the principle of transparency and publish reports on the conducted public procurements which show how the decision on the selection of bidders was made. A special problem was the implementation of public procurement that had already been initiated. The implementation of public procurement procedures has been hampered by increased demand for similar

\footnotetext{
${ }^{3}$ The possibility and manner of redirecting appropriations are prescribed by Article 61 of the Law on Budget System, The Official Gazette of the Republic of Serbia, No. 54/2009... $149 / 2020$, the possibility and manner of using current budget reserve funds by Article 69, and the financing of mandatory social insurance organizations can be done through donations and transfers from the budget by Article 29 of the said Law.
} 
products (medical equipment), disruption of production, export restrictions and prohibition, and limited access to relevant information.

Despite the need to conduct urgent public procurement procedures, it is necessary to control their legality and regularity, bearing in mind that public procurements in Serbia were identified prior to the COVID-19 pandemic as an area prone to corruption in the EU annual reports (2020 EU Report on Serbia, p. 28). However, Serbia was faced with allegations by civil society organizations that during the pandemic, there were irregularities in public procurement procedures. ${ }^{4}$

Integrity violations were intensified across the globe during the COVID-19 pandemic, especially in the form of contracts for protective equipment being awarded to dubious companies and price gouging of key medical and healthcare equipment (Steingrüber et al, 2020). The Supreme Audit Institution of Great Britain also pointed out irregularities in public procurement procedures during the COVID19 pandemic in its 2020 report. $^{5}$

The analysis started from the assumption that due to the short time limit and lack of adequate control during the public procurement procedure, there were many challenges, so the first part of the paper relates to the assessment of the European Union standards according to which it is possible to deviate from the regular public procurement procedure in emergency situations and specifically the European Commission's Guidance on using the public procurement framework in the emergency situation related to the COVID-19 crises (Communication from the Commission, Guidance from the European Commission on using the public procurement framework in the emergency situation related to the COVID-19 crisis, 2020/C 108 I/01, April 1, 2020). In the second part, the measures established at the national level by several countries to enable the implementation of public procurement during emergencies were analysed with the aim of finding out if they were in line with the Guidance and the level of deviation from the public procurement principles. In the end, the measures that have been established in the

\footnotetext{
${ }^{4}$ The civil society organization Transparency Serbia called on state bodies and health institutions to publish relevant information on procurement during the state of emergency, including those to which the provisions of the Law on Public Procurement have not been applied. https://rs.n1info.com/biznis/a586090-transparentnost-objaviti-podatke-o-nabavkama-respiratora-tokom-vanrednog-stanja/. See also: https://voice.org.rs/javnenabavke-u-vanrednom-stanju-neobavezne-obavezne-informacije-sta-je-kupljeno-i-koliko-k osta/. Accessed 6 October 2021.

${ }^{5}$ For more information, see: https://www.nao.org.uk/wp-content/uploads/2020/11/Investigation-into-government-procurement-during-the COVID-19-pandemic.pdf. Accessed 6 October 2021.
} 
Republic of Serbia were assessed in comparison with the irregularities in the implementation of public procurement, which were pointed out by the Supreme Audit Institution of Great Britain (Kostić, 2019). In their documents, international organizations emphasize the importance of the role of audit in the prevention of corruption in urgent public procurement procedures (UNODC, 2020). Bearing in mind that the Supreme Audit Institution of Great Britain has already published its report on the audit of urgent public procurement procedures during the COVID-19 pandemic, as well as the fact that auditing in this country has a long tradition, we analysed the key findings of its Supreme Audit Institution in the context of Serbia's needs. The publication of the UK report is an example of good practice. Based on comparative analysis, the authors proposed recommendations for improving the functioning of public procurement in emergency situations. If the control of public procurement could not be carried out during a state of emergency, it should be performed later. The implementation of control affects the increase in the responsibility of the procuring entity in public procurement procedures as well as the increase in transparency and legality of the procedures.

\section{EUROPEAN STANDARDS AND THE EUROPEAN COMMISSION GUIDANCE}

During the pandemic, the European Commission issued guidelines for the implementation of the public procurement framework in the emergency situation caused by the COVID-19 outbreak. The purpose of the Guidance was to establish a framework for the application of the more flexible provisions in public procurement procedures during the crisis period and to facilitate and speed up the implementation of the public procurement procedure. To protect lives against the new virus, it was necessary in the short term to procure personal protective equipment, such as face masks, protective gloves, and medical devices. The European Commission's Guidance points to the possibility of using shorter deadlines to speed up open or restricted public procurement procedures. In addition, the European Commission emphasizes the possibility of using negotiation procedures without publication if the use of shorter deadlines is not sufficient for fast and efficient procurement of goods and services.

The European Commission's Guidance is based on the provisions of Directive 2014/24/EU on public procurement (The Official Journal of the European Union, No. L 94/65) and refers only to cases of extreme urgency when it is necessary to purchase certain goods within a few days, or possibly hours. According to Article 32 of the Directive, it is possible to negotiate directly with potential contractors without the obligation to publish a tender, time limits, and fulfil other requirements regarding the procedure. These guidelines indicate the possibility of contacting 
potential contractors at all levels inside and outside the European Union by phone, e-mail or similar.

In addition to the above possibilities, according to the provisions of the Directive, it is possible to conduct a negotiated procedure without publishing a call for tenders for the faster award of contracts for the supply of goods necessary to combat the pandemic. In these situations, the deadlines for open and restricted procedures or competitive negotiated procedures cannot be met. The circumstances invoked by the contracting party to justify extreme urgency should be independent of the will of the contracting authority (Article 32 (2) (c) of the Directive).

Each contracting authority is obliged to assess whether the conditions for using such a negotiated procedure are met without prior publication and must explain its choice of procedure in an individual report (Article 84 (1) (f) of Directive 2014/24/EU). The reasoning in the report must confirm that the following criteria are cumulatively met: that the event requiring the application of the procedure was not caused by the will of the contracting parties in the particular case, and that there are special needs for funds necessary for hospitals or other health care institutions. In addition, it must be concluded from the explanation that there was an extreme urgency, which makes it impossible to act within the prescribed deadlines. It is also necessary to explain the existence of a connection between an unforeseen event and extreme urgency. Contracting authorities must also keep in mind that the procedure can be applied only to overcome the problem and find a more acceptable solution. Although the implementation of public procurement in extraordinary circumstances is temporary, in these situations, one should consider not only the transparency of the procedure but also other principles of public procurement.

The European Commission's Guidance refers to the provisions of the Directive which regulate two situations: extreme urgency and emergency. The extreme urgency procedure requires stricter conditions, while an emergency requires shortening the deadlines that normally apply to the open procedure and the usually restricted procedure. Based on that, the deadlines are quite short. The state of extreme urgency further narrows competition in the market. The negotiated procedure without the publication of a call for applications is applicable in such situations and implies that no tender notice is published (Baratta, 2020, pp. 367 and 368). Procedural steps can be legitimately circumvented if there is an exceptional increase in the need for certain goods or services, a significant disruption in the supply chain and if public procurement procedures cannot be carried out due to technical or physical obstacles (Ibid, p. 373).

The Guidance recognised the emergency and the need to find alternative solutions to respond to the COVID-19 crisis. The European Commission, on the other hand, attempted to reconcile public procurement principles with the need 
for rapid acquisition of all the necessary equipment. During an emergency, countries could award contracts without transparency but have an ex-post transparency requirement to publish a contract award notice 30 days after the conclusion of the contract. In addition, the contracting authorities have a duty to keep a detailed record of all decisions, justifications, and actions taken to support transparency and enable ex-post audits.

\section{NATIONAL MEASURES FOR LEGAL AND EFFICIENT PUBLIC PROCUREMENT IN THE TIME OF EMERGENCY}

Having in mind the need for public procurement in special circumstances, in this part, the authors analyse the compliance of measures taken by the following EU member states against the European Commission's Guidance: the Republic of Austria, the Republic of Croatia, the Federal Republic of Germany and the Slovak Republic. Countries were selected based on their size (similar size to Serbia and bigger states), region (neighbouring countries) and EU membership (old and new member states). The comparative assessment will be used as the basis for tailor-made recommendations for Serbia with the aim of ensuring adequate response in possible future unforeseen situations, independent of the will of contracting authorities and bidders, which also need to deviate from regular public procurement procedures.

\section{The Republic of Austria}

The Austrian Parliament did not adopt the regulation that automatically suspends deadlines in public procurement procedures during the state of emergency caused by the coronavirus pandemic but left the decision to contracting authorities. Most contracting authorities suspended the deadlines on their own initiative. In addition, if the contracting authorities did not extend the deadlines, the bidders could request an extension of the deadline in the ongoing public procurement procedures (Cms Law-Now, 2020).

The Austrian Federal Public Procurement Act (the Public Procurement Act of the Republic of Austria from 2018, with the latest amendments from September 26, 2021 (Bundesrecht konsolidiert: Gesamte Rechtsvorschrift für Bundesvergabegesetz 2018, Fassung vom 26.09.2021) allows the use of the negotiated procedure without prior publication if this becomes necessary due to extreme urgency caused by events beyond the control of the contracting authority, which cannot be attributed to it and when deadlines for open, restricted or negotiated procedures are not met (sections 35-37 of the Federal Procurement act of 2018 (Bundesvergabege 2018). Such a possibility was justified for use during a pandemic 
caused by the coronavirus and for the procurement of medical devices, protective equipment, and other goods and services necessary to protect the population from a pandemic.

According to the available information, special measures were taken during the implementation of public procurement procedures, and the use of electronic means was expanded. In addition to the direct award of contracts or the selection of a negotiated procedure without prior publication, the contracting authorities in Austria had the right to shorten the minimum time limits for submitting requests to participate or tenders in urgent cases. In the event that no appropriate tender or request to participate was submitted in an open or restricted procedure, the contracting authority could choose the negotiated procedure without prior publication, provided that the initial terms of the contract were not substantially amended (Cms Law-Now, 2020).

The application of such procedures is also indicated by the European Commission's Guidance in accordance with EU standards. In addition, the Austrian Federal Procurement Act law allows for changes to existing contracts. Therefore, it was possible to apply its provisions if a change due to unforeseen circumstances or replacement of the contractor is needed. Modification of the contract is possible if the need for it arises from circumstances that the client could not foresee, and the change does not modify the nature of the contract. A change of contractor is possible, but only under specific conditions. Such cases are modification of clauses from the concluded contract, or complete or partial replacement of the original contractor after restructuring (e.g. merger, acquisition and insolvency), provided that it does not imply other significant changes to the contract, does not aim to circumvent the law and the contractor meets the criteria for quality selection set by the contracting authority (section 365 of the Public Procurement Act from 2018). According to the Rule of Law Report on Austria, prosecution services highlighted procurement of healthcare equipment and materials as a specific risk area. Stakeholders pointed to large amounts allowed to be spent under emergency procurement procedures, with limited transparency requirements (Rule of Law Report Country Chapter on the rule of law situation in Austria accompanying the Communication from the Commission to the European Parliament, the Council, the European Economic and Social Committee and the Committee of the Regions, 2021, Brussels, 20.7.2021 SWD (2021) 701 final, p. 12).

\section{The Republic of Croatia}

In Croatia, the Ministry of the Economy and Sustainable Development issued specific recommendations aiming at strengthening the public procurement system 
in the context of the pandemic (Recommendation from the Ministry of the Economy, Entrepreneurship and crafts on the issue of prescribing and providing tender guarantees in the new situation caused by the coronavirus outbreak and Recommendation from the Ministry of the Economy, Entrepreneurship and crafts concerning the implementation of a public binding process in the new situation caused by the coronavirus outbreak). During the COVID-19 virus pandemic, a Decision was made to limit the use of funds provided in the state budget of the Republic of Croatia and the financial plans of extra-budgetary users of the state budget for 2020 (Narodne novine, No. 41/2020).

According to the Decision, as of April 3, 2020, budgetary and extra-budgetary users of the state budget were obliged to suspend all public bidding and were not allowed to launch new tenders unless it was necessary to perform their basic tasks and functions (Article 6 Decisions). According to its provisions, the users of public funds could continue the implementation of public procurement procedures and simple procurement procedures if it was necessary for the implementation of measures to help the economy due to the coronavirus epidemic. Also, if it is carried out to repair the damage caused by the earthquake, to obtain equipment needed to fight the coronavirus epidemic, and if there is a justified reason for it.

During the state of emergency, the delivery of guarantees was difficult due to restrictions on movement at the national and international levels. Therefore, it was recommended to the contracting authorities to seek a tender guarantee only if they estimate that the risks for which it is required are likely to be realized, having in mind the value, urgency and importance of the public procurement. It is recommended that if the contracting authority decides to request the delivery of the guarantee, reduce its amount in proportion to the maximum amount allowed by law (which is $3 \%$ of the estimated value of the public procurement), and if it would amount to e.g. $1 \%$ of the estimated value, the guarantee would not be a great burden for bidders (see Articles 214 and 215 of the Law on Public Procurement of the Republic of Croatia, Narodne novine, no 126/2016). In addition, the possibility prescribed by law could be used to pay a cash deposit as a guarantee instead of a bank guarantee. According to the recommendation, proof of payment could be a confirmation of payment via internet banking. Having in mind the epidemiological measures, the recommendation was that the opening of bids is done without the presence of authorized representatives of the bidders or other interested parties. If the authorized representatives expressed a desire to participate in the opening of the bid, the procuring entity was obliged to ensure their participation in accordance with the Government's decision on public gatherings (Decision on necessary epidemiological measures restricting gatherings and introducing other necessary epidemiological measures and recommendations to prevent the 
transmission of the COVID-19 disease through gatherings, Narodne novine, no. $95 / 2021)^{6}$, and if that was not feasible to allow them to participate via video conference if there was a technical possibility. According to the available data, the complaints were delivered by courier and via an electronic communication system (Cms Law-Now, 2020a). In 2020, 66\% of public procurements were under appeal procedure before the State Commission for Supervision of Public Procurement Procedure. According to the Annual Report of the State Commission for the Control of Public Procurement Procedures for 2020, the most common reasons for filing complaints were errors in assessing qualitative criteria for selection of bidders, shortcomings in proving compliance with technical specifications, completion of bids contrary to legal restrictions, unclear and contradictory documentation and approval of certain bidders by prescribing technical specifications (Annual Report of the State Commission for the Control of Public Procurement Procedures for 2020, pp. 45-57). According to the report of the European Commission on the Rule of Law for the Republic of Croatia, and according to the Draft of the Anti-Corruption Strategy for the period 2021-2030, the area of public procurement has been identified as high risk. The draft states that the legislative framework regarding the supervision and transparency of public procurement procedures needs to be improved (The Rule of Law Report, Country Chapter on the rule of law situation in Croatia, accompanying the Communication from the Commission to the European Parliament, the Council, the European Economic and Social Committee, and the Committee of the Regions, Brussels, 20.7.2021 SWD (2021) 713 final, p. 51).

Considering the reasons for complaints considered by the State Commission for Supervision of Public Procurement in 2020, it can be concluded that public procurement procedures in the Republic of Croatia were not fully compliant with the principles of transparency and equal competition, which are incorporated in the European Commission Guidance and EU public procurement standards and had to be applied even during the pandemic.

\section{The Federal Republic of Germany}

During the COVID-19 pandemic in Germany, various measures were also adopted in order to combat the pandemic and improve the response of the public administration. Public procurement procedures were not suspended automatically, and the parliament did not pass a law or regulation suspending deadlines in public procurement procedures. If the procuring entity did not extend the deadline, the

\footnotetext{
${ }^{6}$ The mentioned decision was changed several times after the first publication, in accordance with the epidemiological situation.
} 
bidders could request an extension of the deadline. During the pandemic, the deadline was allowed due to the current situation because the bidders could not collect all the necessary documentation due to external reasons or restrictions imposed by law (Cms Law-Now, 2020b).

During the pandemic, the Federal Ministry of Economy and Energy issued a Decree on the application of the law in public procurement procedures related to the procurement of goods and services related to the prevention of the spread of the SARS-CoV-2 virus corona of March 19, 2020, which entered into force immediately. ${ }^{7}$ The Decree provided guidance for interpreting whether simplified procedures and expedited procedures were allowed during the pandemic. The condition for the application of that procedure is an unforeseen event and extremely urgent and convincing reasons for its application. It was considered that during the pandemic, conditions were fulfilled when it was necessary to procure goods or services intended for the suppression and resolution of the COVID-19 pandemic in the short term or for the maintenance and insurance of public administration. The emergency procurement procedure could be used to procure medicines, disinfectants, disposable gloves, masks, protective equipment, swabs, clothes, medical equipment (ventilator), services necessary during the pandemic, internet technology, video conferencing, etc. (SIGMA, Application of public procurement rules during the COVID-19 crisis from the perspective of the European Union's Procurement Directives and the Government Procurement Agreement, April 2020, p. 10). Contracting authorities are recommended to document the fulfilment of the conditions necessary for the application of the simplified public procurement procedure.

In addition to taking special measures, the use of electronic means during the procurement procedure has been expanded. In Germany, it was possible for contracting authorities to extend the deadlines for the submission of tenders to allow tenderers more time to prepare and submit tender documents or extend or postpone the deadlines for the performance of the obligation. In addition, only one company was allowed to submit a bid under the negotiated procedure without a call for tenders if that company would be able to fulfil the contract according to technical and time constraints due to the urgency of the procurement. Therefore, negotiations or digital presentations within the negotiation process had to be held via video conference. In that way, the realization of the principles of equal treatment, non-discrimination and transparency was enabled (Cms Law-Now, 2020b).

\footnotetext{
${ }^{7}$ The text of the Decree in German is available on the website: https://www.bmwi. de/Redaktion/DE/Downloads/P-R/rundschreiben-anwendung-vergaberecht.pdf?_blob $=$ publicationFile\&v=6. Accessed 6 October 2021.
} 
According to Article 132 (2) of the Anti-Restriction of Competition Act, amendments to existing contracts are possible in terms of extension or extension of contracts. According to that article, it is possible to extend the existing contracts with the consent of the contracting parties, as well as increase the value without conducting a new contract award procedure during the pandemic, for the delivery of medical aids or other means necessary to combat the COVID-19 virus pandemic. According to the mentioned article, the value of the original contract can be increased by $50 \%$ of its value (Anti-competition law (Gesetz gegen Wettbewerbsbeschränkungen). However, in practice, problems were identified in the application of the principles of public procurement. According to the Rule of Law report on Germany, the Financial Intelligence Unite has received an increased number of reports in the context of COVID-19 support measures offered by the Government, including reports on corruption and mostly on fraud. In addition, the alleged reception of kickbacks for parliamentarians who have brokered face mask deals for the Government has led to public debate and the launch of corruption investigations. To enhance the prevention of corruption, including during and after the COVID-19 pandemic, Germany will launch its electronic competition register in support of public procurement processes in 2021 (The Rule of Law Report, Country Chapter on the rule of law situation in Germany, accompanying the Communication from the Commission to the European Parliament, the Council, the European Economic and Social Committee, and the Committee of the Regions, Brussels, 20.7.2021 SWD (2021) 706 final, p. 11).

\section{The Slovak Republic}

In Slovakia, Law No. 62/2020 on certain emergency measures related to the expansion of COVID-19 was adopted on March 25, 2020. Among other provisions, the law introduced amendments to the Law No. 343/2015 on Public Procurement (The Law on Certain Extraordinary Measures in Relation to the Expansion of COVID19 (Zákon o niektorých mimoriadnych opatreniach v súvislosti so šírením nebezpečnej nákazlivej l'udskej choroby COVID-19 a v justícii a ktorým sa menia a doplnnajú niektoré zákony). These amendments allow contracting authorities to conclude a contract, framework agreement or concession with tenderers who are not registered in the Register of Public Sector Partners or whose subcontractors are not registered in that register, provided that a directly negotiated procedure without notice can be used and that such contracts conclude solely for the protection of life and health during a state of emergency or emergency. Such conditions relating to procedures for direct negotiation without notice may be omitted in the case of small-value contracts. The pandemic was recognized as an emergency situation, so the procedure of direct negotiations could be used. The Slovak Public Procurement 
Administration emphasized that even then, public funds must be spent in accordance with the principles of efficiency and transparency. Ongoing procurement procedures were not terminated automatically, and legal deadlines were also not suspended automatically. According to the available data, the contracting parties generally postponed or suspended the deadlines on their own initiative. If the contracting authority did not extend the deadlines, bidders could request an extension of the deadline (especially in situations where it was not possible to collect all documentation for reasons beyond the bidder's control or due to legal restrictions. Simplified procedures were allowed). Accelerated deadlines were allowed due to the urgency of open, restricted or competitive negotiated procedures, while urgency had to be justified by the competent authorities in accordance with the European Commission Guide and EU Directive 2014/24. To ensure equal treatment, competition, and transparency, it was recommended to open bids through video conferencing. If in the public procurement procedure, no appropriate bids were submitted or no suitable bids were offered, the contracting authority had to cancel it. Due to the pandemic, it was recommended that existing contracts, framework agreements or concessions could be amended without initiating a new tender procedure (Cms Law-Now, 2020c). The condition for amendments was that the necessity to change the contract arose from the circumstances that the contracting authority could not foresee even with due diligence and if that change does not affect the nature of the existing contract, framework contract or concession. Legal restrictions were applied to the modification of existing contracts and during the pandemic and additional value should not exceed $50 \%$ of the value of the original contract (section 18 . The Slovak Public Procurement Act, no. 343/2015 Coll).

According to the 2021 EU Rule of Law Report, high-risk sectors that were prone to corruption before the pandemic were also prone to it during the pandemic, including the public procurement sector and the health sector. As part of the sectoral anti-corruption program in the Ministry of Health, a special working group has been established to assess the risk of corruption in the context of the COVID-19 virus pandemic. To shorten the time required for the procurement of goods, services, and construction works during the pandemic, the Government has prepared a draft Law on Amendments to the Law on Public Procurement (The Rule of Law Report, Country Chapter on the rule of law situation in Slovakia, accompanying the Communication from the Commission to the European Parliament, the Council, the European Economic and Social Committee and the Committee of the Regions, Brussels, 20.7.2021 SWD(2021) 727 final, p. 15). All this speaks of the additional need to harmonize public procurement in the Slovak Republic, both in terms of legislation and practice, with the acquis communautaire. 


\section{IMPLEMENTATION OF PUBLIC PROCUREMENT PROCEDURES IN THE REPUBLIC OF SERBIA DURING THE STATE OF EMERGENCY}

According to Article 36, paragraph 1 of the Law on Public Procurement of the Republic of Serbia, it was possible to deviate from the open public procurement procedure. $^{8}$ In accordance with its provisions, the contracting authority could conduct a "negotiation procedure" if due to extreme urgency caused by extraordinary circumstances or unforeseen events whose occurrence did not depend on the will of the contracting authorities, would not be able to conduct the tender. In such situations, it was necessary for the Public Procurement Administration ${ }^{9}$ to give its opinion on the justification. The client could initiate the procedure without waiting and had to contact the Administration to obtain such an opinion. During the state of emergency, no deviation from the provisions of the Law on Public Procurement was allowed. According to the provisions of the said Law, in these situations, it is necessary to respect the principle of competition, take care that the agreed price is not higher than the market and check the quality of delivery. There was still an obligation for procurers to publish information on the initiated and final public procurement procedures on the Public Procurement Portal.

In addition, contracting authorities could refer to the provisions of Article 131, in conjunction with Article 7, paragraph 1, item 3) of the Law on Public Procurement. That article prescribed the possibility for contracting authorities to obtain funds without applying the prescribed procedures if the need for such goods or services is conditioned by natural disasters, the consequences of which endanger the life or health of people or the environment. The virus pandemic was such a circumstance. Given that the needs for goods and services could not be foreseen at the time of drafting the budget and financial plans, it was necessary in emergencies to use the option provided by the Law on Budget System, which prescribes the transfer of money from one budget appropriation to another, budget reserve, and then to a certain appropriation for the purpose of conducting public procurement in extraordinary circumstances.

On April 7, 2020, the Public Procurement Administration issued the Instruction for conducting the public procurement procedure during a state of emergency. This

\footnotetext{
8 This refers to the Law on Public Procurement, Official Gazette of RS, No. 124/2012, 14/2015 and 68/2015, which was valid until the entry into force of the new Law on Public Procurement, Official Gazette of RS, No. 91/2019.

${ }^{9}$ After the entry into force of the new Law on Public Procurement from 2019, the Official Gazette of RS, no. 91/2019, its name was changed. It is now called the Public Procurement Office.
} 
instruction recommends not initiating public procurement procedures if the conditions for that are not met, and the possibility that the other party will not perform the contract is taken into account. The recommendation of the management was that the contracting authorities continue with the implementation of the initiated public procurement procedures, but that they could use the possibility prescribed by Article 109, paragraph 2 of the Law on Public Procurement and suspend the initiated procedure. It is necessary that there are objective reasons that can be proven, which could not have been foreseen at the time of initiating the procedure, and which make it impossible to complete the initiated proceedings. In the instructions, the management pointed out the possibility of continuing the procedure of public procurement when the conditions for their implementation are met (The instructions of the Public Procurement Administration and the notice of the Public Procurement Administration dated March 24, 2020).

\section{HOW TO ENSURE INTEGRITY OF PUBLIC PROCUREMENT DURING THE STATE OF EMERGENCY}

Public procurement is an activity where there is a high risk of corruption. Due to the need for the urgent procurement of medical equipment during the COVID19 pandemic and the possibility of circumventing regular procedures, it was necessary to pay special attention to reducing corrupt activities in these procedures. Therefore, even in such situations, there was a requirement to respect the principle of transparency in public procurement as well as a requirement for responsible public spending. In many countries, public procurement legislation includes exceptions that allow governments to respond rapidly to emergencies in ways that may be inconsistent with the rules that apply in normal times. This might take the form of direct contracting for supplies from producers without going through the processes that normally would be used (Baxter and Casady, 2020).

The approach of Germany highlighted the relevance of strengthening the eprocurement system as an anti-corruption measure and action to increase transparency. In addition, the World Bank recognized e-procurement as a tool that facilitated the continuation of procurements during the pandemic (World Bank, 2021, "Opportunities and Challenges for Public Procurement in the First Months of the COVID-19 Pandemic: Results from an Experts Survey" EFI Insight-Governance. Washington, DC: World Bank). Countries with an existing e-procurement system were able to adjust their public procurement functions more promptly.

Emergency procurement is often conducted with expedited modalities, such as direct contracting, that have less ex-ante oversight and reduced ex-ante 
transparency. This choice is motivated by the necessity of a prompt response to the emergency, but it also implies that ex- post reviews and public scrutiny are imperative. If we take into account the importance of ex-post control of public procurement, especially when ex-ante transparency is restricted, the role of the Supreme Audit Institutions is crucial and Serbian authorities should consider options for their greater involvement (Matić, 2013). Given the possibility of corruption and irregularities in public procurement procedures conducted during a state of emergency, it is necessary that audit procedures are conducted in a timely and comprehensive manner. A good example is a report prepared by the Supreme Audit Institution of Great Britain on the audit of the public procurement system during the pandemic on July 31, 2020. According to the report, there was no adequate documentation regarding the award of the contract without prior publication of a call in some cases. In the majority of cases, there was a lack of explanation of how a particular supplier was selected and how the risks of corruption due to lack of competition were mitigated, especially the conflict of interest. The awarding of contracts retroactively after the start of certain works was also an issue. In addition to the aforementioned report, during August 2020, the Cabinet of Ministers asked the Government's Internal Audit Agency to audit six contracts for the procurement of personal protective equipment, which had attracted media attention in the previous period. ${ }^{10}$ The audit procedure also revealed irregularities, which are reflected in the fact that public procurement contracts did not exist at the time of their implementation. Some contracts were awarded without prior market analysis to individual suppliers. Although the need to act in accordance with the principle of transparency in public procurement procedures is emphasized, a large number of contracts were not published in a timely manner. ${ }^{11}$ Based on the findings, the Supreme Audit Institution of the United Kingdom proposed additional guidelines

\footnotetext{
${ }^{10}$ As can be seen, internal audit also has a significant role in the process of prevention and detection of irregularities in public procurement procedures. However, in the Republic of Control, the system of internal financial control has not been adequately established. About that in: Šuput, J. (2013). „Internal financial control in the public sector [Interna finansijska kontrola u javnom sektoru], in: Rabrenović, A. and Ćeranić, J. (eds.) Usklađivanje prava Republike Srbije sa pravnim tekovinama Evropske unije: prioriteti, problemi, perspektive, Belgrade, Institute of Comparative Law, p. 260.

${ }^{11}$ According to the Instruction of the Crown Commercial Council, it is recommended that contracting authorities publish all information on the award of public procurement contracts within 90 days of award day. However, according to the findings of the Supreme Audit Institution, by the end of July 2020, a total of 55\% of contracting authorities did not publish detailed information within the specified deadline, and $25 \%$ published such information within the deadline.
} 
on the implementation of urgent public procurement procedures with the aim to improve transparency and reasoning behind decisions. One of the recommendations is that procurements conducted by direct procurement from suppliers be documented with proof of the absence of conflicts of interest and unequal treatment in the public procurement procedure (Investigation info Government procurement during the COVID-19 pandemic, Report by the Comptroller and Auditor General, National Audit Office, 29 November 2020).

Having in mind the available information, it seems that the citizens of the Republic of Serbia have been deprived of information on the procurement of medical equipment and means for the fight against the pandemic caused by the COVID-19 outbreak. This approach violated the principle of transparency (Alarm Report on the Situation in the Field of Public Procurement in Serbia, p. 9). To overcome transparency challenges, civil society addressed the competent institutions to get an answer and inform the public about the public procurement procedure. However, the institutions remained silent. ${ }^{12}$ To increase trust, it is important to subsequently conduct the procedure of auditing public procurement procedures during the state of emergency by the Supreme Audit Institution of the Republic of Serbia. Its role is of special importance for strengthening transparency and accountability in public spending (Kostić \& Matić, 2022, p. 57).

\section{REFERENCES}

Alarm Report on the Situation in the Field of Public Procurement in Serbia, retrieved from https://preugovor.org/News/1629/The-New-Alarm-Report-DocumentsState-Capture-in.shtml. Accessed 6 October 2021.

Annual Report of the State Commission for the Control of Public Procurement Procedures for 2020, retrieved from https://sabor.hr/sites/default/files/uploads /sabor/2021-06-18/160702/IZVJ_DRZ_KOMISIJA_KONTROLA_POSTUPAKA_ JAVNE_NABAVE_2020.pdf. Accessed 6 October $20 \overline{21}$.

Anti-competition law (Gesetz gegen Wettbewerbsbeschränkungen), retrieved from http://www.gesetze-im-internet.de/gwb/BJNR252110998.html. Accessed 6 October 2021.

Barrata, R. (2020). "EU Soft Law Instruments as a Tool to Tackle the COVID-19 Crisis: Looking at the "Guidance" on Public Procurement Through the Prism of

\footnotetext{
${ }^{12}$ An example is the address of the organization Transparency Serbia to the Republic Health Insurance Fund regarding the procurement of the 15th Respirator of the Ministry of Health in March 2020.
} 
Solidarity", European Papers, 5(1), retrieved from https://www.european papers.eu/en/system/files/pdf_version/EP_EF_2020_I_033_Roberto_Baratta_0 0384.pdf. Accessed 6 October 2021, pp. 365-373.

Casady, C.B. \& Baxter, D. (2020) "Encouraging and Procuring Healthcare PublicPrivate Partnerships Through Unsolicited Proposals During the Coronavirus (COVID-19) Pandemic!, Journal of Public Procurement, retrieved from https:// www.researchgate.net/publication/341218914. Accessed 6 October 2021.

Cms Law-Now. (2020). Guidance for public procurement procedures in Austria during the COVID-19 crisis, retrieved from https://www.cms-lawnow.com/ ealerts/2020/04/guidance-for-public-procurement-procedures-in-austriaduring-the-covid-19-crisis?cc_lang=en, Accessed 6 October 2021.

Cms Law-Now. (2020a). Guidelines for Public Procurement in Croatia during the COVID-19 Crisis, retrieved from https://www.cms-lawnow.com/ealerts/ 2020/04/guidelines-for-public-procurement-in-croatia-during-the-covid-19crisis?cc_lang=en. Accessed 6 October 2021.

Cms Law-Now. (2020b). A guidance for public procurement procedures in Germany in times of COVID-19, retrieved from https://www.cms-lawnow.com/ealerts/ 2020/04/a-guidance-for-public-procurement-procedures-in-germany-in-timesof-covid-19. Accessed 6 October 2021.

Cms Law-Now. (2020c). A guidance for public procurement procedures in Slovakia in times of COVID-19, Retrieved from https://www.cms-lawnow.com/ealerts /2020/04/a-guidance-for-public-procurement-procedures-in-slovakia-in-timesof-covid-19. Accessed 6 October 2021.

Consolidated version of the Public Procurement Act of the Republic of Austria from 2018, with the latest amendments from September 26, 2021 (Bundesrecht konsolidiert: Gesamte Rechtsvorschrift für Bundesvergabegesetz 2018, Fassung vom 26.09.2021), retrieved from https://www.ris.bka.gv.at/GeltendeFassung. wxe?Abfrage=Bundesnormen\&Gesetzesnummer $=20010295$. Accessed 6 October 2021.

COVID-19 Civic Freedom Tracker, Keep Civic Space Healthy, retrieved from https://www.icnl.org/covid19tracker/?location=\&issue=5\&date=\&type=. Accessed 6 October 2021.

Decision on necessary epidemiological measures restricting gatherings and introducing other necessary epidemiological measures and recommendations to prevent the transmission of COVID-19 disease through gatherings, Narodne novine, no. 95/2021

Decree on the application of the law in public procurement procedures related to the procurement of goods and services related to the prevention of the spread 
of SARS-CoV-2 virus corona of March 19, 2020, which entered into force immediately, retrieved from https://www.bmwi.de/Redaktion/DE/Downloads /P-R/rundschreiben-anwendung-vergaberecht.pdf?__blob=publicationFile $\& v=6$. Accessed 6 October 2021.

Directive 2014/24/EU of the European Parliament and of the Council of 26 February 2014 on public procurement and repealing Directive 2004/18/EC, Official Journal of the European Union, L 94/65. Retrieved from https://eur-lex.europa. eu/legal-content/EN/TXT/?uri=celex\%3A32014L0024. Accessed 6 October 2021.

Guidelines on the optimal and rational supply of medicines to avoid shortages during the COVID-19 outbreak, The Official Journal of the European Union, Cl 116/1, retrieved from https://eur-lex.europa.eu/legal content/EN/TXT/?uri =uriserv\%3AOJ.CI.2020.116.01.0001.01.ENG\&toc=0J\%3AC\%3A2020\%3A116l\% 3ATOC. Accessed 6 October 2021.

Investigation info Government procurement during the COVID-19 pandemic, Report by the Controller and Auditor General, National Audit Office, 29 November 2020, retrieved from https://www.nao.org.uk/wp-content/uploads/2020/11/ Investigation-into-government-procurement-during-the-COVID-19pandemic.pdf. Accessed 6 October 2021.

Kostić, J. (2019). "Supreme Audit Institutions of the Republic of Serbia and the United Kingdom, Comparative Legal Analysis", in: M. Novakovic (ed.), Common Law and Civil Law Today, Convergence and Divergence, Delaware, United States, Vernon Press, pp. 413-435.

Kostić, J. \& Matić, M. (2022). "Financial accountability and transparency of public sector institutions in the Republic of Serbia" in: Accountability and the law, Rights, Authority and Transparency of Public Power, P. Mikuli, \& G. Kuza (eds.), London and New York, Routledge pp. 46-59.

Matić, M. (2013). „Vrhovne reivzorske institucije i borba protiv korupcije“ [Supreme Audit Institution and the fight against corruption], in: J. Ćirić (ed.), Borba protiv korupcije - iskustva i poređenja, Belgrade, Institute of Comparative Law, pp. 123-154.

OECD. (2020). Public Integrity for an Effective COVID-19 Response and Recovery, retrieved from https://www.oecd.org/coronavirus/policy-responses/publicintegrity-for-an-effective-covid-19-response-and-recovery-a5c35d8c/. Accessed 6 October 2021.

Recommendation from the Ministry of the Economy, Entrepreneurship and crafts on the issue of prescribing and providing tender guarantees in the new situation 
caused by the corona virus outbreak. Retrieved from http://www.javna nabava.hr/default.aspx?id=7221. Accessed 6 October 2021.

Recommendation from the Ministry of the Economy, Entrepreneurship and crafts concerning the implementation of a public binding process in the new situation caused by the coronavirus outbreak, retrieved from http://www.javna nabava.hr/default.aspx?id=7220. Accessed 6 October 2021.

Serbia 2020 Report Accompanying the Communication from the Commission to the European Parliament, the Council, the European Economic and Social Committee and the Committee of the Regions 2020 Communication on EU Enlargement Policy, Brussels, 6.10.2020 SWD(2020) 352 final, retrieved from https://ec.europa.eu/neighbourhood-enlargement/system/files/2020-10/ serbia_report_2020.pdf. Accessed 6 October 2021.

SIGMA, Application of public procurement rules during the COVID-19 crises from the perspective of the European Union's Procurement Directives and the Government Procurement Agreement, retrieved from http://www.sigmaweb. org/publications/Public-procurement-COVID-19-crisis-SIGMA-April-2020.pdf. Accessed 6 October 2021.

Steingrüber, S., Kirya, M., Jackson, D. Mullard, S. (2020). Corruption in the time of COVID-19: A double-threat for low income countries, U4 Anti-Corruption Resource Centre, Chr. Michelsen Institute., retrieved from https://www.u4.no/ publications/corruption-in-the-time-of-covid-19-a-double-threat-for-lowincome-countries. Accessed 6 October 2021.

Time. (2021). World Health Organization Declares COVID-19 a 'Pandemic.' Here's What That Means, retrieved from https://time.com/5791661/who-coronaviruspandemic-declaration/. Accessed 6 October 2021.

The Decision on declaring a state of emergency on Mach 15, 2020, The Official Gazette of the Republic of Serbia, No. 29/2020.

The Decision on declaring the COVID-19 disease caused by the SARS-Cov-2 virus a contagious disease was first made on March 10, 2020, The Official Gazette of the Republic of Serbia, No. 23/2020.

The Decision on necessary epidemiological measures restricting gatherings and introducing other necessary epidemiological measures and recommendations to prevent the transmission of COVID-19 disease through gatherings, Narodne novine, no. 95/2021.

The Decision to limit the use of funds provided in the state budget of the Republic of Croatia and the financial plans of extra-budgetary users of the state budget for 2020, Narodne novine, No. 41/2020. 
The Decision on the use of funds from the current budget reserve, The Official Gazette of the Republic of Serbia, No. 47/2020.

The instructions of the Public Procurement Administration of the Republic of Serbia, retrieved from https://www.propisi.net/uprava-za-javne-nabavke-sprovodjenjepostupaka-javnih-nabavki-u-toku-vanrednog-stanja/. Accessed 6 October 2021.

The Law on Budget System, The Official Gazette of the Republic of Serbia, No. 54/2009... 149/2020.

The Law on Certain Extraordinary Measures in Relation to the Expansion of COVID19 (Zákon o niektorých mimoriadnych opatreniach v súvislosti so šírením nebezpečnej nákazlivej l'udskej choroby COVID-19 a v justícii a ktorým sa menia a doplňajú niektoré zákony) Retrieved from https://www.slov-lex.sk/pravnepredpisy/SK/ZZ/2020/62/. Accessed 6 October 2021.

The Law on Public Procuremen of the Republic of Croatia, Narodne novine, no. $126 / 2016$.

The Law on Public Procurement of the Republic of Serbia, Official Gazette of RS, No. $124 / 2012,14 / 2015$ and 68/2015.

The notice of the Public Procurement Administration dated March 24, 2020, retrieved from http://www.ujn.gov.rs/vesti/obavestenje-u-vezi-sa-sprovodjenjem-postupaka-javnih-nabavki-u-toku-vanrednog-stanja/. Accessed 6 October 2021.

The Public Procurement Act of the Republic of Austria from 2018, with the latest amendments from September 26, 2021 (Bundesrecht konsolidiert: Gesamte Rechtsvorschrift für Bundesvergabegesetz 2018, Fassung vom 26.09.2021.

The Rule of Law Report, Country Chapter on the rule of law situation in Austria accompanying the Communication from the Commission to the European Parliament, the Council, the European Economic and Social Committee and the Committee of the Regions, 2021, Brussels, 20.7.2021 SWD(2021) 701 final. Retrieved from https://ec.europa.eu/info/sites/default/files/2021_rolr_ country_chapter_austria_en.pdf. Accessed 6 October 2021.

The Rule of Law Report, Country Chapter on the rule of law situation in Croatia, accompanying the Communication from the Commission to the European Parliament, the Council, the European Economic and Social Committee and the Committee of the Regions, Brussels, 20.7.2021 SWD(2021) 713 final, retrieved from https://ec.europa.eu/info/sites/default/files/2021_rolr_country_chapter croatia_en.pdf. Accessed 6 October 2021.

The Rule of Law Report, Country Chapter on the rule of law situation in Germany, accompanying the Communication from the Commission to the European Parliament, the Council, the European Economic and Social Committee and the 
Committee of the Regions, Brussels, 20.7.2021 SWD(2021) 706 final, retrieved from 2021_rolr_country_chapter_germany_en.pdf (europa.eu). Accessed 6 October 2021.

The Rule of Law Report, Country Chapter on the rule of law situation in Slovakia, accompanying the Communication from the Commission to the European Parliament, the Council, the European Economic and Social Committee and the Committee of the Regions, Brussels, 20.7.2021 SWD(2021) 727 final, retrieved from https://ec.europa.eu/info/sites/default/files/2021_rolr_country_chapter _slovakia_en.pdf. Accessed 6 October 2021.

The Slovak Public Procurement Act, no. 343/2015 Coll.

UNODC. (2020). COVID-19 vaccines and corruption risks: preventing corruption in the manufacture, allocation and distribution of vaccines, retrieved from https://www.unodc.org/documents/corruption/COVID-19/Policy_paper_on_ COVID-19_vaccines_and_corruption_risks.pdf, Accessed 6 October 2021.

World Bank. (2021). "Opportunities and Challenges for Public Procurement in the First Months of the COVID-19 Pandemic: Results from an Experts Survey" EFI Insight-Governance. Washington, DC, World Bank.

Šuput, J. (2013). „Interna finansijska kontrola u javnom sektoru“ [Internal financial control in the public sector], In: A. Rabrenović, J Ćeranić, (eds.), Usklađivanje prava Republike Srbije sa pravnim tekovinama Evropske unije: prioriteti, problemi, perspekrive, Belgrade, Institute of Comparative Law, pp. 247-261. 